\title{
Reptilia, Serpentes, Dipsadidae, Gomesophis brasiliensis (Gomes, 1918): Distribution extension in state of Santa Catarina, Brazil
}

\author{
Vanessa Barbisan Fortes ${ }^{1,3 *}$, Elaine Maria Lucas $^{2}$ and Vinícius Matheus Caldart ${ }^{3}$ \\ 1 Universidade Federal de Santa Maria. Avenida Independência, 3751. CEP 98300-000. Palmeira das Missões, RS, Brazil. \\ 2 Universidade Comunitária da Região de Chapecó. Rua Senador Atílio Fontana, 591E. CEP 89809-000. Chapecó, SC, Brazil. \\ 3 Universidade Federal de Santa Maria, Programa de Pós-graduação em Biodiversidade Animal, Centro de Ciências Naturais e Exatas. Avenida \\ Roraima s/ nº, sala 1140. CEP 97105-900. Santa Maria, RS, Brazil. \\ * Corresponding author: barbisan.vanessa@gmail.com
}

\begin{abstract}
The Brazilian burrowing snake, Gomesophis brasiliensis, occurs in aquatic habitats such as swamps, from Minas Gerais and Distrito Federal until Rio Grande do Sul. In spite of this wide distribution, the species' geographic range still remains unclear. This note reports the occurrence of $G$. brasiliensis in the municipality of Vargem Bonita, state of Santa Catarina, south Brazil, extending the species' range $c a .80 \mathrm{~km}$ to the west in this state.
\end{abstract}

The Gomesophis genus, which belongs to the Tachymenini tribe, comprises only one species, the Brazilian burrowing snake G. brasiliensis (Gomes, 1918). This species is associated to aquatic habitats and it is frequently found burrowed in the mud (Prudente and Brandão 1998; Lema 2002; França and Araújo 2007). Its diet includes earthworms, which is a derived character to the group (Oliveira et al. 2003). Specimens analyzed by Oliveira et al. (2003) revealed a seasonal reproduction, associated to the rainy season.

In spite of a wide distribution, just few records exist for this species and its geographic range remains unclear. G. brasiliensis type locality is Pindamonhangaba, state of São Paulo, Brazil (Gomes 1918). According to Peters and Orejas-Miranda (1970) this species occurs in the states of Minas Gerais, São Paulo, Paraná and Rio Grande do Sul. It has also been recorded in Central Brazil, in Águas Emendadas Ecological Station, Distrito Federal (Prudente and Brandão 1998). In state of Santa Catarina G. brasiliensis was known from only one locality until recently, Alto Vale

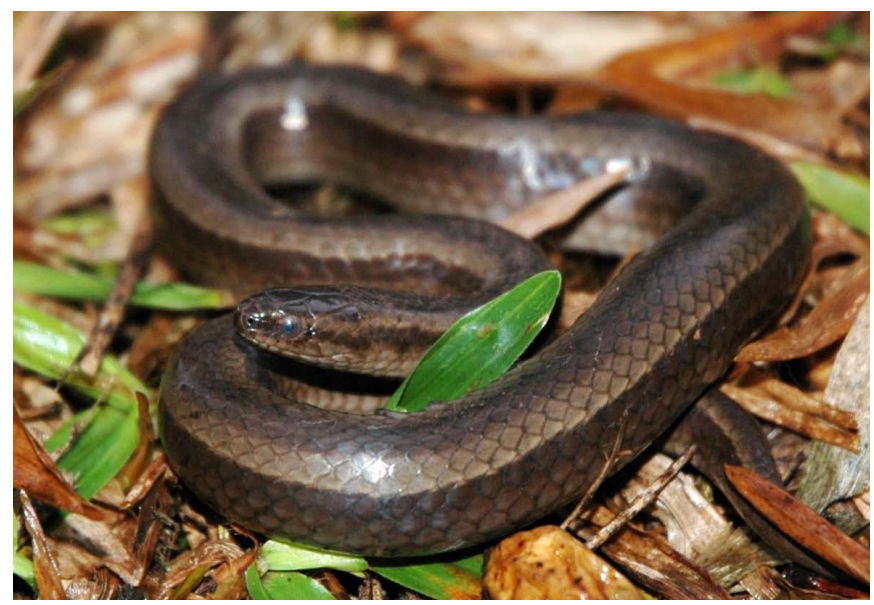

FIGURE 1. Specimen of Brazilian burrowing snake, Gomesophis brasiliensis, captured in Vargem Bonita, state of Santa Catarina, Brazil. Photo by Eliara S. Müller. do Itajaí (municipality of Rio do Campo; R. S. Bérnils, pers. comm.) (Bérnils et al. 2001), however, Ghizoni Jr. et al. (2009) recorded the species' occurrence in four additional municipalities (Caçador, Fraiburgo, Canoinhas, and Porto União).

We observed two specimens in a private property named Fazenda São Pedro (2653'48” S, 5142'05" W; $655 \mathrm{~m}$ above sea level) on October $18^{\text {th }} 2008$. The area belongs to Seara Alimentos Company and is located in the municipality of Vargem Bonita, west of state of Santa Catarina, Brazil. The closest municipality where the species' occurrence is documented (Caçador) is about 80 $\mathrm{km}$ far from there. Timber extraction (planted trees) is the main activity in the area nowadays, but the Ombrophylous Mixed Forest (Brazilian pine forest) covered it originally. Individuals were found active, around 21:00 h, moving in the water surface, distant about $1.5 \mathrm{~m}$ between them. Just one individual could be captured, which was deposited in the herpetological collection of the Universidade Comunitária Regional de Chapecó (CSUC 0125; CRA = 270 $\mathrm{mm}$; CC = $52 \mathrm{~mm}$; 21g; Figure 1).

The place where we found the specimens is a pond with muddy bottom and turbid water, with approximately $80 \mathrm{~cm}$ deep, located in an open area near Pinus stands. Herbaceous aquatic macrophytes (emergent and floating) are found as inside as in the shore of the pond. The outer edge of the pond is covered by a fen where the most typical vegetal species are mosses (Sphagnum sp.). The occurrence of $G$. brasiliensis in swamps with fens was already mentioned by Lema (2002). The habitat where G. brasiliensis was registered in Vargem Bonita is probably similar to that where the species lives in Serra Gaúcha (Lema 2002) and Alto Vale do Itajaí (Bérnils et al. 2001), since those places correspond to the same vegetal formation.

Most of the known distribution of $G$. brasiliensis is related to the Plata Basin. This is the second largest river basin in South America, and it is highly threatened by hydroelectric impoundments (Wong et al. 2007), facing 
the second greatest number of planned dams in the world (WWF 2004). In this way, habitat destruction by flooding (among other processes) can actually put this species at risk in such areas. Until date São Paulo and Minas Gerais are the only Brazilian states where the conservation status of $G$. brasiliensis was assessed, both including it in the Least Concern category (Biodiversitas 2007; Bressan et al. 2009). This is the most Western record for G. brasiliensis in the state of Santa Catarina (Figure 2), and potentially contributes to the species knowledge and protection.

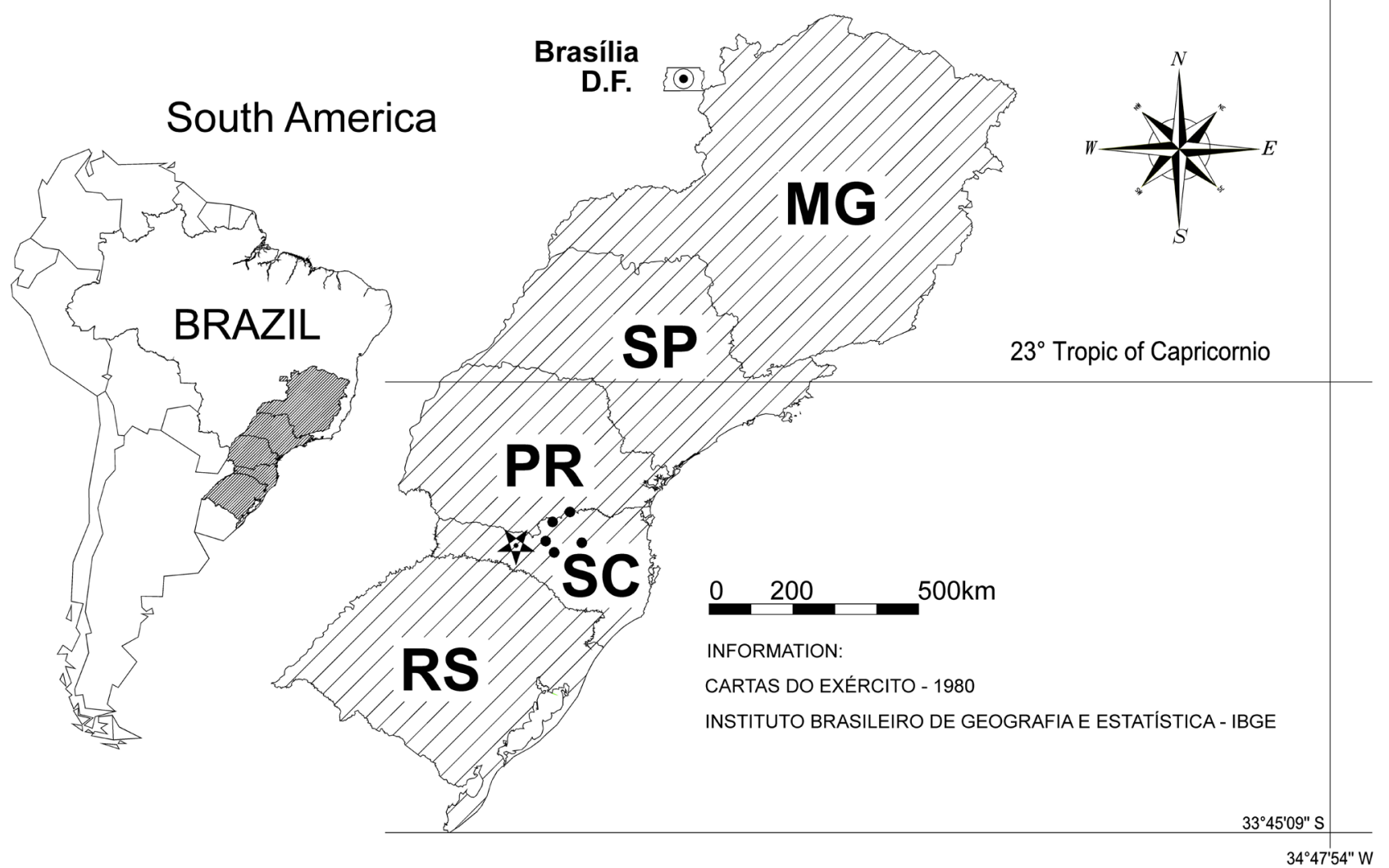

FIGURE 2. Brazilian states and Federal District, where Gomesophis brasiliensis occurs. The localities where the species was previously recorded in Santa Catarina (Caçador, Canoinhas, Fraiburgo, Porto União and Rio do Campo) are indicated by dots and the new locality (Vargem Bonita) by a star. RS: state of Rio Grande do Sul; SC: state of Santa Catarina; PR: state of Paraná; SP: state of São Paulo; MG: state of Minas Gerais.

ACKNOWLEDgments: The authors are grateful to S. T. Z. Cechin for the stimulus to write this note, to F. M. D'Agostini and G. M. de SouzaFranco for the critical comments and to R. S. Bérnils for the additional information about the species occurrence.

\section{Literature Cited}

Bérnils, R.S., M.A. Batista and P.W. Bertelli. 2001. Cobras e lagartos do Vale: levantamento das espécies de Squamata (Reptilia, Lepidosauria) da Bacia do Rio Itajaí, Santa Catarina, Brasil. Revista de Estudos Ambientais 3(1): 69-79.

Biodiversitas. 2007. Revisão das listas das espécies da flora e da fauna ameaçadas de extinção do estado de Minas Gerais. Relatório final, vol. 3. Electronic database accessible at http://www.biodiversitas.org. br/listas-mg/RelatorioListasmg_Vol3.pdf. Belo Horizonte. Captured on 21 July 2010.

Bressan, P.M., M.C.M. Kierulf, and A.M. Sugieda. 2009. Fauna Ameaçada de Extinção do Estado de São Paulo: Vertebrados. São Paulo: Fundação Parque Zoológico de São Paulo / Secretaria do Meio Ambiente. 645 p.

França, F.G.R. and A.F.B. Araújo. 2007. Are there co-occurrence patterns that structure snake communities in Central Brazil? Brazilian Journal of Biology 67(1): 33-40.

Gomes, J.F. 1918. Contribuição para o conhecimento dos ofidios do Brasil. III (1). Memórias do Instituto Butantan 1(1): 57-83.

Ghizoni Jr., I.R., T.S. Kunz, J.J. Cherem and R.S. Bérnils. 2009. Registros notáveis de répteis de áreas abertas naturais do planalto e litoral do estado de Santa Catarina, sul do Brasil. Biotemas 22(3): 129-141.
Lema, T. 2002. Os répteis do Rio Grande do Sul: atuais e fósseis, biogeografia, ofidismo. Porto Alegre: EDIPUCRS.

Oliveira, J.L., M. Borges and O.A.V. Marques. 2003. Gomesophis brasiliensis. Reproduction and Diet. Herpetological Review 34(3): 251.

Peters, J.A. and B. Orejas-Miranda. 1970. Catalogue of Neotropical Squamata, Part I: Snakes. Bulletin of the United States National Museum 297: 1-347.

Prudente, A.L.C. and R. Brandão. 1998. Gomesophis brasiliensis. Herpetological Review 29(2): 112.

Wong, C.M., C.E. Williams, J. Pittock, U. Collier and P. Schelle. 2007. World's top 10 rivers at risk. Electronic database accessible at http://assets. panda.org/ downloads/worldstop10riversatrisk final march13.pdf. WWF International: Gland, Switzerland. Captured on 30 December 2008.

WWF (World Wide Fund for Nature). 2004. Dam Right: Rivers at Risk. Electronic database accessible at https://intranet.panda.org/data/ downloads/10060/riversatriskfinalfullreport.pdf. WWF Dams Initiative. WWF International: Gland, Switzerland. Captured on 30 December 2008.

RECEIVED: May 2009

REVISED: March 2010

ACCEPTED: April 2010

Published ONLINE: September 2010

EDITORIAL RESPONSIBILITY: Alejandro R. Giraudo 